ROCZNIKI HUMANISTYCZNE

Tom LXIX, zeszyt 11 - 2021

ZESZYT SPECJALNY / SPECIAL ISSUE

DOI: https://doi.org/10.18290/rh216911-9s

MARK Ó FIONNÁIN

\title{
THE CELTIC LANGUAGES IN THE СРАВНИТЕЛЬНЫЕ СЛОВАРИ (1787-1789): AN INTRODUCTION
}

\begin{abstract}
A b s t r a c t. In the 1780s, a multilingual dictionary was published in Saint Petersburg in the Russian Empire, under the editorship of the German Peter Simon Pallas (1741-1811). As its titleСравнительные Словари Всьхъ Языковъ и Наръчій [Comparative Vocabularies of all Languages and Dialects] - explains, it aimed to be a comparative dictionary of almost 300 headwords and numbers in Russian and their equivalents in 200 languages and dialects from all over Europe and Asia. Amongst these are five of the six Celtic languages - Irish, Scottish Gaelic, Welsh, Cornish and Breton, as well as an unknown "Celtic" - and this paper gives a brief overview of the background to the dictionary, and then focuses on the first 10 lexemes in each of the Celtic languages as they are presented in the dictionary itself, pointing out various inaccuracies, but also the historical value therein.
\end{abstract}

Keywords: Peter Simon Pallas; Celtic languages; Сравнительные Словари; comparative vocabularies.

\section{INTRODUCTION}

A multilingual comparative dictionary printed in Saint Petersburg in the Russian Empire in 1787-1789 under the editorship of the German Peter Simon Pallas (1741-1811), the Сравнительные Словари Встьхь Языковъ u Нарғчиій [Comparative Vocabularies of all Languages and Dialects, henceforth Vocabularies] lists almost 300 words in Russian and their equivalents in 200 languages and dialects from across Europe and Asia. Amongst the linguistic families to be found in this dictionary are the Celtic languages, and

Mark Ó FIONNÁIN, PhD, The John Paul II Catholic University of Lublin, Institute of Linguistics, Department of Celtic Studies; e-mail: mark.ofionnain@kul.pl. ORCID: https://orcid.org/0000-00033345-8475. 
this dictionary is thus a brief picture of the Celtic languages from the late 1700 s as seen through the prism of Russian and the Cyrillic alphabet. However, despite the attention paid to this work over the years, and to various languages therein e.g. Albanian, French, Romanian, Portuguese, Spanish, and several Slavic languages, e.g. Polish, Polabian, Ukrainian, Czech, Old Church Slavonic, very little attention has been paid to the Celtic linguistic family itself, even though they occupy second position in the dictionary, after the Slavic languages, and ahead of the Romance and Germanic. The only research on the Celtic family that has been carried out is that on Breton by Gargadennec and Laurent in French, with a brief summary of same by Muradova in English, two articles on Irish (in Irish) and Scottish Gaelic (in English) by the author of this paper, as well as one general conference talk by Bulatovas and Nooij. The aim of this essay is therefore to give a brief background to the history of the dictionary and to then take a closer look, albeit a necessarily brief one given the scope of the original work, at how the Celtic languages themselves are presented in the work, with a particular focus on the initial first ten lexemes as they are presented in the six languages as a representative example, as these cover the first two items in the work'God' and 'heaven' - and the following set of eight lexemes related to family and kinship.

\section{BACKGROUND ${ }^{1}$}

Pallas's comparative dictionary was actually the culmination of work which really began several years previously, when another German, Ludwig Christian Bacmeister (1730-1806), a State Councillor and Deputy Librarian at the Imperial Academy, published his Объявленіе и Прошеніе Касаюшїяся до Собранїя Разныхъ Языковъ въ Примторахъ [An announcement and request concerning the gathering of various languages in examples] in 1773. This was

\footnotetext{
${ }^{1}$ The history of the dictionary has been covered many times in various languages to a greater or lesser extent, frequently as part of a discussion of a particular language in the dictionary itself, e.g. Russian (Kaminskaya, Voloshina), French (Bochnakowa), Spanish (Stala), Irish (Ó Fionnáin, "An Ghaeilge"). Other works discuss the dictionary in more detail in relation to Pallas's own life and works (e.g. Wendland (491-504) in German, Archaimbault in French), Catherine the Great's interest in linguistics (e.g. Adelung (39-106) in German, Ivinskiy in Russian, Juszkiewicz in Polish) or the history of linguistics in Russia in general (e.g. Bulich (219-32), Jagić (70-72), both in Russian). As such, the historical background given above is necessarily brief, and the reader is directed to the latter sources especially for more detailed accounts.
} 
a request to record samples of as many languages as possible according to the plan that Bacmeister himself laid out in the self-same pamphlet. This pamphlet can be divided into three parts. In the first, he lays down the best method of recording the phonetics of the samples requested, for example that they should be transcribed in French, if possible, if not, then German, but that Latin should be avoided. Furthermore, he requests that the sources and their names and social status also be recorded, as too the region in which the language is spoken. In the third part, Bacmeister gives the example of one phrase taken from the Bible (Romans 13:1) and shows how it was translated from Russian into Arabic, French into Finnish, German into Swedish and Latin into Finnish, in an effort to show how translation is possible even if disparate languages do not contain the same turns of phrase.

It is the second part ("Рьчи для переводу" $23 \mathrm{ff}$.), however, that is of interest: it is here that he gives the list of phrases which he wishes to be translated. Amongst these are the numbers 1-22, the tens from 30-100 (including, for some reason, 71 and 99), 200 and 1,000. He then gives 22 phrases and sentences that were also to be translated, including, as a representative example, these, relating to parts of the body: ${ }^{2}$

10. Носъ по середи лица. 'The nose is in the middle of the face.'

11. У насъ двъ ноги, и на каждой рукъ по пяти пальцевъ. 'We have two legs, and five fingers on each hand.'

12. Волосы ростуть на головъ. 'Hair grows on the head.'

13. Языкъ и зубы во рту. 'The tongue and the teeth are in the mouth.'

14. Правая рука сильнЊе львой. 'The right hand is stronger than the left.'

15. Волосъ дологъ и тонокъ. Кровь красная. Кости кръпки какъ камень. 'A hair is long and thin. Blood is red. Bones are strong like stone.'

Bacmeister's pamphlet was sent far and wide to various people of learning, and, as a result of his request, he received a lot of information from various sources. For example, Adelung (Catherinens der Grossen 26-31) states that Bacmeister had in his possession 72 whole translations, 5 incomplete sets of translations and 24 lists of words and grammatical notes, but nothing came of it. ${ }^{3}$ It is worth noting at this juncture that only two Celtic languages appear in the list of materials as given by Adelung-Irish and Scottish Gaelic.

\footnotetext{
${ }^{2}$ See Klubkova ("Pervyy Rossiyskiy") for more on Bacmeister's wordlist. She makes the point that, strange as such sentences may seem, they are linked by ideas and concepts, and that Bacmeister was looking for words in context and not merely random lists of vocabulary.

${ }^{3}$ Adelung (25) states that Bacmeister seems to have lost interest, or at least that he never communicated his results to the world. Possibly the length of time taken played a part; in the same
} 
Independently of this enterprise, Catherine the Great herself (1729-1796), the Empress of the Russian Empire at this time, had also been considering producing a comparative list of vocabularies and had even set about compiling a list of her own, which eventually consisted of 200 basic words, and translations into 159 languages. She had been inspired to this course of action by reading Court de Gébelin's unfinished Monde Primitif (9 vols., 1773-1782), in which he discusses the origins of language, religion and civilisation, and as a result of which, as she wrote in a letter to a friend, she had noted that Celtic resembled Ostyak ${ }^{4}$ ("Ceci m'a appris que le Celte ressemble à l'Ostiaque"), the language of a tribe from Siberia (Adelung 40). As a result of this enthusiasm, she even requested the noted German bookseller Friedrich Nicolai (1733-1811) to obtain for her "all the reference books she would need for a comparative lexicon of all languages, living and dead" (Selwyn 149), which were subsequently located for her. Thus, as a cumulative result of Bacmeister's original materials, Catherine's interest and Nicolai's procurements, there was much linguistic material available by the middle of the 1780s; it just needed something to be done with this all, and to this end Catherine appointed Pallas to the job.

Pallas was already well known when appointed. He was a doctor and naturalist, he had explored Siberia and the north and east of Asia, he was an expert on Siberian and Mongolian flora and fauna, and clearly was a favourite of Catherine's. Although he had no linguistic experience, he accepted the post as editor and as a result the dictionary eventually came out. It was issued in two parts, the first in 1787 , the second in 1789 , and although it is stated to be a comparative vocabulary of all languages and dialects, it is actually limited to those of Europe, Asia and острововъ Южнаго Окїана [of the islands of the Southern Ocean]. ${ }^{5}$

\section{THE CELTIC LANGUAGES IN THE VOCABULARIES}

In Pallas's dictionary there are 273 basic words and the numbers 1-10, 100 and 1,000. Each page is divided into two columns, and the Russian headword

paragraph Adelung mentions material being collected over a period of fifteen years. In any case, Bacmeister did not give up totally, as in 1784 he was contemplating a second edition of his request (Adelung 31-32).

${ }^{4}$ Now called Khanty/Hanti.

${ }^{5}$ A second volume containing languages from the Americas and Africa was expected to be produced but did not appear, although some material was collected. 
is given at the top of the page, and there then follow the translations in the 200 languages and dialects. The translations are listed according to numbers, followed by the name of the language and the headword in that language (see the illustration at end). Amongst the themes of the words listed are those concerned with family members, parts of the body, nature/plants/ animals, household and farming, colours, numbers, and so forth.

The Celtic linguistic family occupies the second set of positions in the dictionary (numbers 13-19), after various languages from the Slavic linguistic family (numbers 1-12). They are listed as follows: number, 13 is "in Celtic" (По Кельтски), followed by "in Breton" (По Бретански, no. 14), "in Irish" (По Ирландски, no. 16), “in Erzo-Shotlandski," i.e. Scottish Erse (По ЭрзоШотландски, no. 17), “in Welsh" (По Валски, nо. 18) and "in Cornish” (По Корнвалски, no. 19). Manx is thus the only modern Celtic language missing. ${ }^{6}$ At number 15 there is Basque, which might seem out of place nowadays, but in the eighteenth century there was the widespread belief that Basque was, in fact, a Celtic language, a belief which was still in vogue some time later. ${ }^{7}$

\subsection{Breton}

As was noted previously, Breton is the only Celtic language that has been previously looked at from the point of view of this dictionary, by Gargadennec and Laurent in French, and with a brief English-language summary of the same article by Muradova. In the first half of their article, Gargadennec relates how he tracked down the dictionary after having found references to it in various archived letters, whilst Laurent then presents an analysis of the Breton in the dictionary itself, in consultation with the renowned Breton scholar Roparz Hemon. Hemon (Gargadennec and Laurent 813-814) notes that there is both north and south Breton given, but that many of the spellings (as far as can be made out from the Cyrillic) would seem to match in great part that given in Rostrenen's dictionary (1732), one of the lexicographical sources mentioned by Pallas in the list of works consulted which he provides in his introduction ("Предисловіе") to his dictionary.

\footnotetext{
${ }^{6}$ Although Adelung notes that various material for the dictionary kept coming in after the project was completed and that amongst these language samples was that "von der Insel Man" (103). Furthermore, Manx is to be found in Lhuyd's dictionary, which Pallas mentions as one of the lexicographical sources used in compiling his work.

${ }^{7}$ See, for example, Reid (ix) from the 1830 s, where Basque is still listed as one of the "dialects" of Celtic.
} 
Although Breton has been discussed before, the table below gives the first ten words in Breton for comparison and completion:

\begin{tabular}{|c|c|c|}
\hline & Pallas $^{8}$ & Breton $^{9}$ \\
\hline god & дуэ, доэ /duœ//doœ/ & Doue \\
\hline heaven & $\begin{array}{l}\text { ээ, энъ, эфъ, нефъ } \\
\text { /œœ/ /œn/ /œf/ /nef/ }\end{array}$ & an en \\
\hline father & татъ /tat/ & un tad \\
\hline mother & мамъ /mam/ & ur mamm / vamm \\
\hline son & мапь /map/ & ur pautr \\
\hline daughter & мерхъ /merx/ & ur merc'h / verc'h \\
\hline brother & брарь /brar/ & ar breuzr \\
\hline sister & гоарь /hoar/ & ar c'hoar \\
\hline husband & оцакъ /otsak/ & an ozac'h \\
\hline wife & грекъ, урекъ /grek/ /urek/ & ar c'hrecg \\
\hline
\end{tabular}

\section{2 "Celtic"}

Of this mysterious "Celtic," Muradova says "it is not clear to which Celtic language this referred" (144), although her article is mostly a summary of that by Gargadennec and Laurent, in which Laurent suggests that this Celtic is, actually, an attempt by Bacmeister to recreate "le Celte primordial" or ProtoCeltic (822). In turn, Bulatovas and Nooij claim that this "Celtic," in fact, consists of words from the three Brythonic languages in the following percentages: Welsh (53\%); Welsh, Breton or Cornish (18\%); Welsh or Breton $(16 \%)$; Breton $(11 \%)$; Welsh or Cornish $(2 \%)$, and thus that "Celtic" language is "mainly Welsh, with some Breton." If this is true, then was Bacmeister possibly trying to recreate the original Brythonic language and not Proto-Celtic? Did he maybe feel that Irish and Scottish Gaelic originated from the Brythonic languages? It should also be noted that the first language of the European language families in the Vocabularies could be seen as the "ancestral" language: the Slavic languages are headed by Old Church Slavonic; Modern Greek is preceded by [Old] Greek; Italian, Neapolitan, Spanish

\footnotetext{
${ }^{8}$ The phonetics given here are based on the explanations offered in Pallas on how to read the Russian letters in the dictionary ("Explicatio litterarum Alphabeti Roflici").

${ }^{9}$ As given by Laurent (824).
} 
and Portuguese by Latin; French and Romanian by "Romance and Old French"; and the Germanic by Gothic, followed by Anglo-Saxon. Thus, in such circumstances, it would be logical that the "ancestor" of the Celtic languages should also appear.

Whilst the true origin or purpose of this recreated "Celtic" is thus unclear, below is a table comparing Bacmeister's possible attempted recreation of "le Celte primordial" and modern "reconstructed" Proto-Celtic where possible, as given in Matasović:

\begin{tabular}{|c|c|c|}
\hline & Bacmeister & Proto-Celtic \\
\hline god & дїу, ю /di:u/, /ju/ & *dēwo- \\
\hline heaven & нефи /nefi/ & *nemos- \\
\hline father & атъ /at/ & *mātīr \\
\hline mother & ма /ma/ & *makWo- \\
\hline son & мабъ /mab/ & *brātīr \\
\hline daughter & мержъ /merz/ & *duxtīr / *merkā 'maiden' \\
\hline brother & браотъ /braot/ & *swesūr / *swesr-os \\
\hline sister & жоаэръ /зoaœr/ & прїодъ /pri:od/ \\
\hline husband & брїоди /bri:od/ & \\
\hline wife & & \\
\hline
\end{tabular}

\subsection{Cornish}

Regarding Cornish, the last reputed native speaker of Cornish, Dolly Pentreath, died in 1777. Although it has been the subject of debate as to whether Pentreath was truly the last speaker, the language itself had passed from being a community language some time before that, and, thus, it can be assumed that the words have been taken from Lhuyd's 1707 dictionary, which is also to be found in Pallas's list of lexicographical sources. Indeed, a look at the first ten words in the dictionary show that Pallas's transcription matches Lhuyd's vocabulary very well:

\begin{tabular}{|c|c|c|}
\hline & Pallas & Lhuyd \\
\hline god & деy $/$ deu/ & deu \\
\hline heaven & неевъ $/$ neev/ & nẽv \\
\hline
\end{tabular}




\begin{tabular}{|c|c|c|}
\hline father & таазъ $/$ taaz/ & tàz \\
\hline mother & мамъ $/ \mathrm{mam} /$ & mam \\
\hline son & маабъ $/ \mathrm{maab} /$ & màb \\
\hline daughter & меръ $/ \mathrm{mer} /$ & merh \\
\hline brother & бредаръ $/$ bredar/ & bredar \\
\hline sister & горъ $/$ hor/ & hor \\
\hline husband & гуусъ, гуаасъ $/$ guus//guaas/ \\
\hline wife & гуреегъ $/$ gureeg/ & gurêg \\
\hline
\end{tabular}

For example, where Lhuyd has a diacritic, be it $\langle\sim\rangle$ or 〈〉, Pallas renders it with a double vowel in the Russian; thus, ne्e is transcribed as неевъ /neev/, màb as маабъ /maab/, gurêg as гypeezъ/gureeg/ and guâz as both гyycъ /guus/ and гуаась/guaas/. Indeed, the few mistakes in the first ten lexemes are the omission of the $\langle\mathrm{h}\rangle$ in the word merh, transcribed as $м е р ъ / \mathrm{mer} /$, and that fact that the final $\langle\mathrm{Z}\rangle$ in guâz is represented by $\langle\mathrm{S}\rangle$ in $2 y y c z / g u u s /$ and $2 y a a c b$ /guaas/. However, it is worth taking a brief look at some of the other entries in the Cornish vocabulary outside of the first ten lexemes, as a comparison with Lhuyd's work shows up some errors that would not be so visible in such a limited analysis of the lexemes.

Lhuyd, for example, provides no Cornish word for 'love', and this is faithfully represented in Pallas's work where the relevant Cornish entry is a line of dots, the method used by Pallas (186) to show that a language was lacking the term in question. However, the word for 'war', which is also omitted by Lhuyd, mysteriously appears as абанъ /aban/ in Pallas (184). One possible reason for this is that, in the same entry in Lhuyd (44) under bellum, the Welsh words for 'war' are listed as rhyvel, bruydr, faban, kad. Aban is here marked as obsolete, but it is not beyond the realms of possibility that Bacmeister felt the need to restore to Cornish a word that it apparently lacked, and thus opted for one that was so old in Cornish's sister language that it had fallen into disuse. If Bacmeister was attempting to recreate Proto-Celtic, maybe he was also trying to recreate some of the absences in Cornish as well.

A further example of this crossover between Cornish and Welsh can be seen in the words given for 'field'. In Lhuyd (42), the Cornish is tîr, guêal, whilst the Welsh is maes, kae, koetgae, maenol, tîr, rhandir. As tîr occurs in both languages, it may be assumed that, when copying out the word, the transcriber (Pallas? Bacmeister? someone else?) looked at the wrong entry and thus 
copied out the wrong word after tîr, possibly as a result of the compactness and density of print in Lhuyd's work itself, which does not make it an easy read. In any case, the Cornish that is offered the reader of the dictionary is тирь, рандирь /tir//randir/, which are the last two examples of the Welsh entry in Lhuyd. It can also be seen here that despite the fact that $t \hat{\imath} r$ possesses a diacritic, there is no corresponding double vowel in the Russian transcription.

Thus, whilst the initial impression of the Cornish in Pallas might seem to be a faithful reproduction of that in Lhuyd, further investigation reveals errors, confusion and invention, although it cannot be said for certain who is at fault. In any case, despite its loss as a community language by this stage of the $1700 \mathrm{~s}$, it is worth noting that Cornish is present in this dictionary of $8 \mathrm{cr} b \mathrm{xb}$ языковъ и наргчиій [all languages and dialects], despite the fact that other, more vibrant, tongues, such as Scots, are not, even though such material was collated (Adelung 30).

\subsection{Welsh}

Adelung (26-31) lists all of the linguistic material that Bacmeister had in his possession, and there is no Welsh ("Walisch") to be found. This is of interest as, at this stage, Welsh, like Irish and Scottish Gaelic, were strong, vibrant, community languages, unlike Cornish, yet apparently no vocabulary was provided. This is even more noteworthy, as the Welsh naturalist and traveller Thomas Pennant (1726-1798) supplied vocabulary for Bacmeister's work in Irish, Scottish Gaelic and Scots, but seemingly did not offer any Welsh.

Pallas, in his list of lexicographical works, names both Lhuyd's work and Davies' Latin-Welsh dictionary (1632), and if there was no Welsh wordlist made available, it would seem that Pallas must therefore have relied on these lexicographical materials. Bearing that in mind, the first ten lexemes for Welsh are given below from Pallas and the equivalent entries in both Lhuyd and Davies:

\begin{tabular}{|c|c|c|c|}
\hline & Pallas & Lhuyd & Davies \\
\hline god & дїy $/ \mathrm{di}: \mathrm{u} /$ & dyu & duw \\
\hline heaven & неевъ $/$ neev/ & név & nef \\
\hline father & таадъ /taad/ & tad & tâd \\
\hline mother & $\begin{array}{c}\text { мамъ, мамуидъ } \\
\text { /mam//mamuid/ }\end{array}$ & mam, mamuyth & mamamws \\
\hline
\end{tabular}




\begin{tabular}{|c|c|c|c|}
\hline son & габъ /gab/ & mab & mab \\
\hline daughter & мерхъ /merx/ & merch \\
\hline brother & браадъ /braad/ & xuaer & brawd \\
\hline sister & хуаръ /xuar/ & gûr priod & gŵr priod gwraig \\
\hline husband & фрїодъ /fri:od/ & guraig & gwraig \\
\hline wife & гурясъ /guræs/ & & \\
\hline
\end{tabular}

Although Pallas mentions both Lhuyd's work and Davies' in his Introduction amongst the lexicographical sources used, it is not clear to which extent each of them was used. The diacritic and the letter $\langle\mathrm{V}\rangle$ in the word for 'heaven', i.e. неевъ, more resembles Lhuyd's név than Davies' nef, but the double Russian vowel in maadz is more akin to Davies' tâd than Lhuyd's tad. The mistake in габъ for $m a b$ cannot be found in either of the Welsh works, and the two words offered by Pallas as 'mother' are actually the first and third entries (of four) in both Lhuyd and Davies, although the $-y u \partial z$ ending again more resembles Lhuyd's - uyth than Davies' -wys. Of the remaining words, there is little to be gleaned from them, as where there are inconsistencies it is not clear why this might be so: why is there an 〈e〉 missing in xyaps even though both Lhuyd and Davies have it, and why is -aud (or $-a w d$ ) given as - $-a а \partial b$ in браaдb 'brother', with a double vowel, as there is no diacritic and thus $-a y \partial b$ would have been a better Cyrillic representation? Of further interest are the last two items, of which 'husband' $\phi p \ddot{0} о \partial$ b /fri:od/ would seem to be linked to priod which is given in both Lhuyd and Davies as part of a compound, namely gur priod in Lhuyd and gîr priod gwraig in Davies, and these are not even the first items in the lists given in the works; gur priod is second in Lhuyd's list and gîr priod gwraig fourth in Davies'. Pallas's word for 'wife'—гурясъ /guræs/—is even more interesting, as it does not appear with a final 〈s〉 in either Lhuyd or Davies. Such discrepancies would seem to suggest that Pallas-or Bacmeister - did not rely solely on these two lexicographical works, and possibly some vocabulary list was returned to Bacmeister which would help explain the errors in mab and the choice of words for husband and wife.

\subsection{Scottish Gaelic ${ }^{10}$}

${ }^{10}$ See Ó Fionnáin (“Erzo-Shotlandskiy”) for a more detailed account of Scottish Gaelic in the dictionary. 
Unlike in the previous cases with Welsh and Cornish, material in Scottish Gaelic was provided for Bacmeister, in this case by the Welshman Thomas Pennant. In Adelung's list the language is termed "Galisch," but in Pallas's work it goes under the name of Эрзо-Шотландский (Scottish Erse). The first ten lexemes in the dictionary are given below, alongside the Scottish Gaelic words they represent:

\begin{tabular}{|c|c|c|}
\hline & Pallas & Scottish Gaelic \\
\hline god & дїа /di:a/ & dia \\
\hline heaven & фляөеньнясь /flæ $\theta$ en'næs/ & flaitheanas \\
\hline father & аөерь /aقer/ & athair \\
\hline mother & маөерь /maقer/ & màthair \\
\hline son & махдъ /maxd/ & $\operatorname{mac}$ \\
\hline daughter & неонтанъ /neontan/ & nighean (?) \\
\hline brother & браөеръ /braӨer/ & bràthair \\
\hline sister & фїуөаръ /fi:uөar/ & phiuthar \\
\hline husband & ферпозда /ferpozda/ & fear-pòsda \\
\hline wife & бъинфозда /benfozda/ ${ }^{11}$ & bean-phòsda \\
\hline
\end{tabular}

Several problems with the Gaelic vocabulary can immediately be ascertained. Amongst these are the use of the Russian letter $\langle\theta\rangle$ to represent the voiceless dental fricative $/ \theta$ / ("ut eadem graecorum littera vel uti th anglorum"), even though it is generally accepted that $/ \theta /$ (and its voiced counterpart $/ ð /$ ) had died out from Gaelic and Irish's common ancestral language by the twelfth or thirteenth century (McManus (351); O'Rahilly, "Notes," although O'Rahilly does suggest that / $/$ / possibly survived somewhat longer in Gaelic (O'Rahilly, Irish Dialects 75)). Other issues to be seen in the representation of Gaelic is the retention of some initial mutations, i.e. sister piuthar is given as /fi:u $\theta \mathrm{ar} /$ and not / $\mathrm{p}^{\mathrm{j} u h ə r /,}$ and the general confusion in transcribing Latin letters into Cyrillic - presumably/neontan/ is intended to be nighean as there is a certain similarity between the two (and nighean is the Gaelic for 'daughter'), but the misrepresentation of the Latin letters in the Russian distorts the final attempt. On the other hand, it should be noted here that

\footnotetext{
${ }^{11}$ Pallas gives no indication of what sound the hard sign 〈ъ〉 is supposed to represent when in the middle of words.
} 
despite the more orthographical-based transcription (i.e. representing 〈th〉 as $/ \theta /$ and not $/ \mathrm{h} /$ ), there is an attempt at a correct phonetic representation of $\mathrm{mac}$ /maxk/, which seems to be somewhat of an anomaly, in that we have here a correct phonetic transcription alongside correct orthographical ones.

Bulatovas and Nooij claim that the Gaelic is taken "with very few exceptions" from Alasdair mac Mhaighstir Alasdair's Leabhar a Theagafc Ainminnin (1741), which is not impossible, but does raise some further questions. Whilst some of the words in Leabhar are given and spelt the same as in Pallas's work above, i.e. dia, athair, mathair, mac, brathair, fer pósda and bean phósda, some are not: 'heaven' is rendered as flaitheamhnas, which does not match the flaithean(n)as given in the Cyrillic; Mac Mhaighstir Alasdair gives two choices for 'daughter' - nion and inghein - neither of which are accurately represented, and the rendition of 'sister' in Leabhar is actually piuar, which is a precise representation of the pronunciation, but not of the standard orthography, which contains a -th-in the middle and which is so shown in the Cyrillic rendition.

\subsection{Irish ${ }^{12}$}

All of the issues discussed above in relation to Scottish Gaelic come to the fore in the depiction of Irish in Pallas's work, where the potential Russian reader is faced with initial mutations retained, incorrect orthography and misleading words. The first ten lexemes are given below:

\begin{tabular}{|c|c|c|}
\hline & Pallas & Irish \\
\hline god & ия /iœ/ & [dh]ia \\
\hline heaven & фэдеръ $/$ fœeder/ & athair \\
\hline father & атэръ $/$ atœr/ & máthair \\
\hline mother & магэръ $/$ mahœr/ & mac \\
\hline son & макъ $/ \mathrm{mak} /$ & gean (inghean = inín) \\
\hline daughter & геанъ $/$ gean/ & bráthair \\
\hline brother & братэръ $/$ bratœr/ & deirbhshiúr \\
\hline sister & деирсвиръ /deirsvir/ & \\
\hline
\end{tabular}

${ }^{12}$ See Ó Fionnáin (“An Ghaeilge”) for a more detailed account of Irish (in Irish) in the dictionary. Bulatovas and Nooij claim that $48 \%$ of the Irish words "could come solely" from Lhuyd's work, with another $12 \%$ from Lhuyd and another source. 


\begin{tabular}{|c|c|c|}
\hline husband & фаръ $/$ far/ & fear \\
\hline wife & бэнъ /bœn/ & bean \\
\hline
\end{tabular}

Amongst the problems met in the examples given above are the retention of mutations where they should not exist, e.g. dia /di:a/ is given as dhia/ji:a/, and inconsistencies in the transcription of the original words: i.e. athair is given as /atœr/, where the original 〈th $\rangle$ has been reduced to a mere $/ \mathrm{t} /$, while in máthair the 〈th〉 is given its correct phonetic representation of $/ \mathrm{h} /$. There is also some confusion in the words chosen: gean and bráthair are older forms of the current inion and deartháir (i.e. inghean and dearbhráthair in the older orthography), whilst deirbhshiur represents the more modern form of 'sister' (now spelt deirfiurr). A further curio is the word for 'heaven', which is actually neamh in Irish. It would seem that, somewhere, this word ended up being confused with the Irish for '[the] prayer', resulting in, presumably, [an] phaidir being shown as the Irish for 'heaven'. Indeed, the Irish name for the Pater Noster is simply An Phaidir 'The Prayer' and it is possible that this is the meaning of the word in question. ${ }^{13}$

\section{SUMMARY}

The aim of this paper was to give a short history of this early attempt at a comparative dictionary from Russia, and to take a brief introductory look at the representations of the Celtic languages in the same, based on the initial ten lexemes in all six of the languages presented in the dictionary. A full and thorough analysis of even one of the Celtic languages represented in the dictionary, never mind all six, would be beyond the scope and limits of the this paper, although it might provide some further insight: for example, how much of the Cornish is inaccurate; how much of the Welsh comes from Lhuyd or from Davies or from another, as yet unknown, source; how error-strewn are the Irish and Scottish Gaelic entries, especially in light of them being the only two for which Bacmeister received responses, and how many of the lexemes might actually be based on Lhuyd or Mac Mhaighstir Alasdair. It should also be noted here that research in the archives on the original wordlists sent to Bacmeister could yield more information regarding what was sent and how any errors occurred. Nevertheless, from the first ten lexemes of each of the

\footnotetext{
${ }^{13}$ My thanks to Prof. Aidan Doyle of University College, Cork, for reminding me of this.
} 
languages that are presented above, we can see how the Celtic linguistic family was initially portrayed: for the most part reasonably accurately, although there are several faults to be found in even such small samples, and a full analysis would surely reveal many more.

It cannot be said for sure why the Celtic languages are the second linguistic family presented in the dictionary, although as Catherine the Great had noted that "Celtic" resembled "Ostyak," possibly the relationship between languages at the far end of Europe and Siberia was deemed to be significant, especially in light of the strength of the Celtic languages in the eighteenth century. Also of possible significance might be the dictionaries listed by Pallas as having been used and consulted for the work, seven of the ten of which (including Lhuyd and Davies) dealt with various Celtic languages, and one of the results of which is the appearance of Cornish in the dictionary despite its moribund status, and the possible attempt to replicate some form of (Proto)"Celtic."

Pallas's dictionary in general tends to be overlooked or discussed only briefly from both a linguistic and lexicographical point of view, as it was one of several such collections of vocabularies gathered in the eighteenth century, and was issued just before the start of the nineteenth century and the new linguistic emphasis placed on comparing related linguistic families and the grammars of such languages, as opposed to just lists of words from languages in general. However, it is of no small significance in its own right, despite its many flaws and errors - it presented lists of vocabularies which had been systematically collated and which were up-to-date for the $1780 \mathrm{~s}$, it tried to find links between various languages and-especially in the case of Bacmeister's initial research-it developed, for the era that was in it, new scientific methods and approaches, and the Celtic languages help stand as testament to that. 


\section{I. Б 0 Г В.}

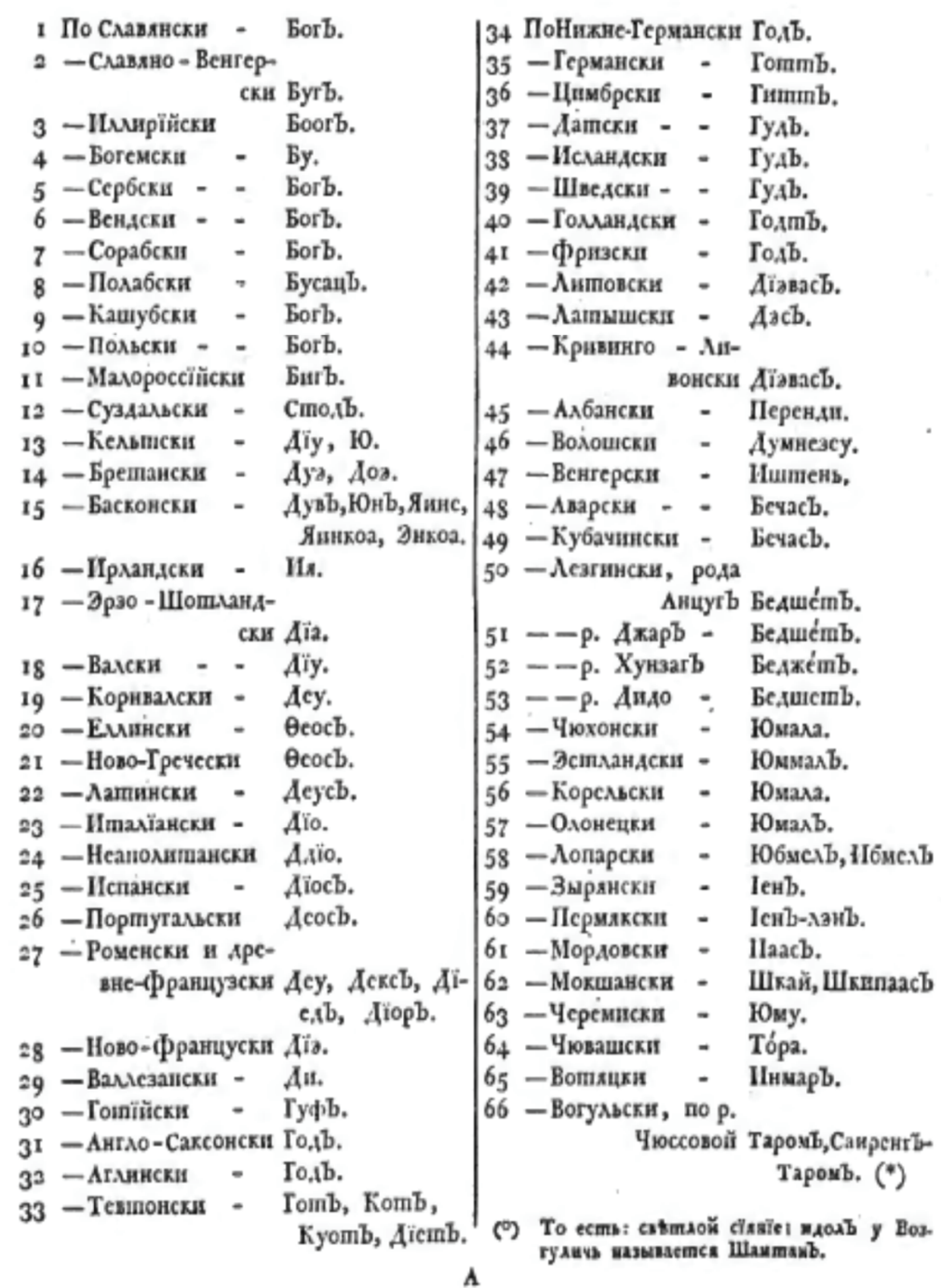

The first word, Богъ 'God', in Pallas's Vocabularies. The Celtic languages occupy positions 13-19: "Celtic," Breton, [Basque], Irish, Scottish Gaelic, Welsh, Cornish. 


\section{WORKS CITED}

Adelung, Friedrich. Catherinens der Grossen Verdienste um die Vergleichende Sprachenkunde. Saint Petersburg, 1815.

Archaimbault, Sylvie. "Peter Simon Pallas (1741-1811), un Naturaliste parmi les Mots." Histoire Épistémologie Langage, vol. 32, no. 1, 2010, pp. 69-91.

Bacmeister, Ludwig. Obyavlenie i proshenie kasayushchiesya do sobraniya raznykh yazykov v primerakh. Saint Petersburg, 1773 [Бакмейстер, Людвиг. Объявленіе и Прошеніе Касаюшїяся до Собранїя Разныхъ Языковъ въ Примърахъ. Санкт-Петербург, 1773].

Bochnakowa, Anna. "'Linguarum totius orbis Vocabularia comparativa Augustissimae cura collecta (...)', 1787-1789.” Studia Linguistica Universitatis Iagellonicae Cracoviensis, vol. 129, no. 1, 2013, pp. 41-50.

Bulatovas, Romanas, and Lars Nooij. “The Celtic Languages in Pallas' Little-Known, 18th Century, Russian Thesaurus." Paper given at the Henry Sweet Society for the History of Linguistic Ideas. Annual Colloquium, 5-8 Sept. 2018, Maynooth University, Ireland.

Bulich, Sergey. Ocherk Istorii Yazykoznaniya v Rossii. Tipografiya M. Merkusheva, 1904 [Булич, Сергей. Очерк Истории Языкознания в России. Типография М. Меркушева, 1904].

Davies, John. Antiquce linguce Britannicee, nunc vulgo dictee Cambro-Britannicce, a suis Cymracee vel Cambrica ab aliis Wallica, et linguce Latince dictionarium duplex. Impress. in ædibus R. Young, impensis Joan. Davies, 1632.

Gargadennec, Roger, and Charles Laurent. "Le Dictionnaire Breton de Catherine de Russie." Annales de Bretagne, vol. 75, no. 4, 1968, pp. 789-833.

Jagić, Vatroslav. Istoriya slavyanskoy filologii. Tipografiya Imperatorskoy Akademii Nauk, 1910 [Ягич, Ватрослав (Игнатий). Исторія Славянской Филологіи. Типография Императорской Академіи Наук, 1910].

Juszkiewicz, Urszula. "Porównawczy słownik Katarzyny II na tle rozwoju rosyjskiego języka literackiego XVIII wieku." Annales Universitatis Mariae Curie-Skłodowska. Sectio F, Nauki Humanistyczne, vol. 30, 1975, pp. 157-168.

Kaminskaya, Larisa. "K istorii sozdaniya pervogo rossiyskogo universalnogo slovarya 1787, 1789 gg." Uchenyye zapiski Novgorodskogo Gosudarstvennogo Universiteta imeni Yaroslava Mudrogo, vol. 1, по. 5, 2016, pp. 1-4 [Каминская, Лариса. «К истории создания первого российского универсального словаря 1787, 1789 гг.» Ученые записки Новгородского Государственного Университета илени Ярослава Мудрого, т. 1, № 5, 2016, сс. 1-4].

Klubkova, Tatyana. "Pervyy Rossiyskiy lingvisticheskiy oprosnik [Первый Российский лингвистический опросник]." Bulletin of the Kalmyk Institute for Humanities of the Russian Academy of Sciences, vol. 23, no. 1, 2016, pp. 181-188.

Lhuyd, Edward. Archceologia Britannica, Giving Some Account Additional to what has been hitherto Publish'd, of the Languages, Histories and Customs of the Original Inhabitants of Great Britain: From Collections and Observations in Travels through Wales, Cornwal, Bas-Bretagne, Ireland and Scotland. Vol. 1, Glossography. Oxford, 1707.

Mac Mhaighstir Alasdair, Alasdair. Leabhar a Teagafc Ainminnin. Robert Fleming, 1741.

Matasović, Ranko. Etymological Dictionary of Proto-Celtic. Brill, 2009.

McManus, Damien. "An Nua-Ghaeilge Chlasaiceach.” Stair na Gaeilge in Ómós do P[h]ádraig Ó Fiannachta, edited by Liam Breatnach et al., Coláiste Phádraig, 1994, pp. 335-446. 
Muradova, Anna. "Some Breton Words in the Dictionary of the Russian Empress." Parallels between Celtic and Slavic, edited by Séamas Mac Mathúna and Maxim Fomin, December Publications, 2006, pp. 143-148.

Ó Fionnáin, Mark, forthcoming. "An Ghaeilge trí Shúile an Rúisigh sna 1780í: Сравнительные Словари Peter Simon Pallas.” Éigse, vol. 41.

Ó Fionnáin, Mark. "'Erzo-Shotlandskiy' in Peter Simon Pallas's Сравнительные Словари." ANGLICA: An International Journal of English Studies, vol. 29, no. 3, 2020, pp. 113-123.

O'Rahilly, Thomas. "Notes on Middle-Irish Pronunciation." Hermathena, vol. 20, no. 44, 1926, pp. 152-195.

O'Rahilly, Thomas. Irish Dialects Past and Present. Dublin Institute for Advanced Studies, 1930 [1988].

Pallas, Peter Simon. Sravnitelnyye Slovari Vsekh Yazykov i Narechiy. Saint Petersburg, 1787, 1789 [Паллас, Петр Симон. Сравнительные Словари Встххъ Языковъ и Наречій. Санкт-Петербург, 1787, 1789].

Reid, John. Bibliotheca Scoto-Celtica; or, An account of all the books which have been printed in the Gaelic Language. John Reid \& Co., 1832.

Selwyn, Pamela. Everyday Life in the German Book Trade: Friedrich Nicolai as Bookseller and Publisher in the Age of Enlightenment 1750-1810. Pennsylvania State UP, 2000.

Stala, Ewa. "Diccionario de Catalina la Grande (1787-1789). Análisis del Material Español." Studia Iberystyczne, vol. 10, 2011, pp. 151-163.

Voloshina, Oksana. “'Sravnitelnyy Slovar Vsekh Yazykov’ Petra Simona Pallasa.” Filologiya: Vestnik Nizhegorodskogo Universiteta im. N. I. Lobachevskogo, vol. 6, no. 1, 2012, pp. 354-361 [Волошина, Оксана. «,„равнительный Словарь Всех Языков“ Петра Симона Палласа». Филология: Вестник Нижегородского Университета им. Н. И. Лобачевского, т. 6, № 1, 2012, cc. 354-361].

Wendland, Folkwart. Peter Simon Pallas (1741-1811) Materialien Einer Biographie. Part 1, Mouton de Gruyter, 1991.

\section{JEZZYKI CELTYCKIE W СРАВНИТЕЛЬНЫЕ СЛОВАРИ (1787-1789): WSTĘP}

$$
\text { Streszczenie }
$$

Pod koniec XVIII wieku w Petersburgu opublikowano wielojęzyczny słownik, którego redaktorem był niemiecki uczony - Peter Simon Pallas (1741-1811). Zgodnie z tytułem - Сравнительные Словари Всъъхъ Языковъ и Наргччій (Słownik porównawczy wszystkich języków i dialektów) - miał to być wielojęzyczny słownik zawierający 300 haseł i liczby z języka rosyjskiego oraz ich odpowiedniki w 200 językach i dialektach z terenów Europy i Azji. Pośród nich jest sześć języków celtyckich - irlandzki, szkocki, walijski, kornwalijski (kornicki), bretoński, oraz nieznany „celtycki”. Artykuł skrótowo przedstawia historię powstania słownika oraz skupia się na analizie 10 wybranych leksemów z każdego z wymienionych języków celtyckich wskazując na różne nieścisłości, jak również podkreślając wartość historyczną haseł zawartych w słowniku.

Przektad angielskiego abstraktu Maria Bloch-Trojnar

Słowa kluczowe: Peter Simon Pallas; języki celtyckie; Сравнительные Словари; słownik wielojęzyczny. 